\author{
Justyna Legutko ${ }^{1}$ \\ Jagiellonian University in Kraków \\ ORCID 0000-0003-4771-4468
}

\title{
TADEUSZ STRUMIŁŁO’S WRITING AND SCOUT ACTIVITIES
}

Summary: The achievements of many Polish educators from the inter-war period were ignored during the Polish People's Republic, contributing to the loss of their legacy despite the political upheaval of 1989. One such example is Tadeusz Strumiłło, whose legacy has not been investigated to date, despite the fact that it contains scientific materials from the philosophical, through pedagogical, social problems and their prevention, to the scout movement. The legacy of Strumiłło shows pedagogical thought and his participation in organising and promoting the scout movement in Poland, entering the scout organisation through the Eleusis Association, and his participation in organising Polish scouting from the very beginning of its existence on Polish soil. He was also among those who laid the foundations of the scouting movement, was an active participant in it and performed key functions, as well as co-created its ideological shape. Additionally, he contributed significantly to the unification of the scouts into a uniform organisation of the Polish Scouting Association.

Keywords: Tadeusz Strumiłło, scout, scouting, pedagogical creativity, dissemination scout movement

\section{Introduction}

Communism in Poland resulted in that the achievements of many outstanding Polish educators from the inter-war period became marginalised. Their legacy was usually preserved by the immediate families or hidden in library archives in anticipation of a change in the political situation. After 1989, some of this legacy lived to see studies on scientific grounds, but much was forgotten.

${ }^{1}$ Justyna Legutko - PhD student at the Institute of Pedagogy in the Faculty of Philosophy of the Department of Higher Education and Polish Pedagogical Thought, ul. Batorego 12, 31-135 Kraków, Poland; e-mail: jlegutko2@gmail.com. 
Such was the case of one of the prominent inter-war pedagogy representatives, Tadeusz Strumiłło ${ }^{2}$. He was a doctor of philosophy, educator and scouting instructor, Chief Scoutmaster of the Republic of Poland, a member of the Eleusis Association, promoter of "quadruple abstinence", scientist and writer. Analysis of the literature shows a lack of comprehensive, synthetic studies on Strumiłło's creative and educational activities on scientific grounds. A small part of his activity emerges here and there, mostly in literature on scouting. In the literature published in the PRL, Strumiłło is mentioned in, among others, Jerzy Gaj's ${ }^{4}$ and Henryk Glass's ${ }^{5}$ studies.

After 1989, some information about Strumiłło re-emerges once again, albeit incomplete, imprecise and sometimes containing conflicting content ${ }^{6}$.

The analysis of his legacy implies that Strumiłło was a social and organisational activist in the scouting movement and in the Eleusis Association founded by Wincenty Lutosławski (later renamed as the Filaret Els Association) and an activist for the prevention and combatting of alcoholism ${ }^{7}$. He was one of the 'Elses' who contributed to the revival of the Union of Hope, an alcohol abstinence society existing since the nineteenth century, in $1909^{8}$. He was also active in many other social and scientific organisations ${ }^{9}$ and, through his activities, he strove towards the moral improvement and national revival of society, including

2 Tadeusz Strumiłło (1884-1958) born in Smiła (Ukraine), in the family of Zofia nee Obrąpalska and Władysław Strumiłło, d. in Poznań. He studied philosophy and art history at the Jagiellonian University, Faculty of Philosophy, philosophy at University College London and the University of Lviv where earned a doctorate in philosophy (1917). He taught at the University of Lublin, the Pedagogical Institute in Katowice, and the Poznań University. Hanna Romaniuk, "Tadeusz Strumiłło (1884-1958)", in: W trosce o trzeźwość narodu. Sylwetki najwybitniejszych działaczy trzeźwościowych XIX i XX wieku, vol. IV, ed. Marian Romaniuk (Warszawa: Ed. Yamaco 2007), 365-384.

${ }_{3}$ T. Strumiłło belonged to a patriotic and religious organization named Eleusis (the members referred to themselves as "Elses"), founded by Wincenty Lutosławski in 1903, which promoted abstinence from tobacco, alcohol, gambling, and debauchery. Teresa Podgórska, Stowarzyszenie Patriotyczno-Religijne "Eleusis” w latach 1902-1914 (Lublin: RW KUL 1999), 27-28.

${ }^{4}$ Jerzy Gaj, "Miejsce Tadeusza Strumiłly w historii harcerstwa", Roczniki Naukowe WSWF (1965), 103-137; Jerzy Gaj, "Prof. dr Tadeusz Strumiłło - wspomnienia pośmiertne”, Harcerska Kuźnia 8-10 (1958), 3-8.

${ }^{5}$ Henryk Glass, "Budujemy Z.H.P. - lata 1919-1931”, Harcerski Volume Historyczny 6 (1979), t. $2,9-10$.

${ }^{6}$ See eg.: Janusz Wojtycza, “Strumiłło Tadeusz", in: Harcerski słownik biograficzny, vol. I, ed. Janusz Wojtycza (Warszawa: Muzeum Harcerstwa 2006), 205-207; Romaniuk, "Tadeusz Strumiłło...", 365-384; Podgórska, Stowarzyszenie..., 27-30.

7 T. Strumiłło was a member of the Trzeźwość [Sobriety] Society for Combating Alcoholism and the Eleuterja-Wyzwolenie [Liberation] Society. He spoke, among others, at Anti-Alcohol Congresses and courses on the dangers of alcohol and ways of fighting it.

${ }^{8}$ Wojciech Hausner, Marek Wierzbicki, Sto lat harcerstwa (Warszawa: Instytut Pamięci Narodowej 2015), 12.

9 T. Strumiłło was a member of many organizations, such as the ZET Association of Polish Youth, the Folk School Society, the Academic Society of Mary, the Polish Philosophical Society, and the Society of Polish Applied Art. 
the production of an intellectual elite to constitute a solid national foundation. Strumiłło's input into the Polish scouting movement is unquestionable. He was one of the movement's early founders and also had an impact on its ideological development. Moreover, he was a journalist, writer and editor.

Bearing in mind the above-mentioned merits of Strumiłło, especially in the field of scouting, the purpose of the article is to show Strumiłło's main areas of publishing activity and its pedagogical aspect as the foundation for his scouting activity. This will assist in filling a gap in current pedagogical knowledge.

\section{The extensiveness of Tadeusz Strumiłło’s legacy}

The research I conducted reveals the size of Strumiłło's bulk of work, numbering several thousand pages. It consists of manuscripts and typescripts; there are diaries, private notes, correspondence, invitations, photographs and articles published in journals, and book publications. This legacy is scattered across many libraries and archives, as well as in family archives ${ }^{10}$. The most comprehensive collection is located in the University Library at the KUL JPII in Lublin. It is a gift of Strumiłło's wife, Stefania, who donated it in 1977 in the hope that it be developed in the future. Other materials are found in the PAN Archives in Warsaw, the Archive of the Jagiellonian Library in Kraków, and the Ossolineum National Institute in Wrocław.

Strumiłło's legacy includes materials on the activities of the Eleusis by various authors (regulations and statutes, internal correspondence, official letters, records of the Board, and reports of its meetings, reports of Filaret council meetings, photographs, manuscripts, and issues of the Eleusis magazine), and the Scouts (including orders, reports from meetings, and official letters). Among the numerous documents, manuscripts and typescripts by Strumiłło on the issues mentioned above can be found - in addition to the articles - notes, comments and speeches, including materials relating to popularising abstinence from alcohol. Correspondence is a large portion of the legacy as well. Strumiłło exchanged letters as a member of the Eleusis and scoutmaster, and as a private person.

Strumiłło's scientific output includes summaries of the most important works of philosophers and educators, from Plato to Strumiłło's contemporaries, sketches and notes of his lectures, including his travel notes on education (his "pedagogical trip"11 around Europe which he made in 1937).

${ }^{10}$ Strumiłło's family holds the educator’s diaries, which he wrote most of his life. They were made available to me by his granddaughter, Ewa Jaxa-Chamiec. Currently, there is no consent of all the heirs to use their content.

${ }^{11}$ Tadeusz Strumiłło, “Harcerskie refleksje z podróży pedagogicznej”, Harcerstwo 1-2 (1938), 46-62. 
Materials constituting Strumiłło’s scientific output can be divided into several core areas. The first of them includes philosophical writings (archives containing many of Strumiłło's manuscripts, including summaries of the most important works of philosophers and educators, from Plato to Strumiłło's contemporaries). The next is the pedagogical area (in the field of upbringing, education) - summary of pedagogical concepts, sketches and notes of his lectures and own notes, including his travel notes on education (his "pedagogical trip"12 around Europe which he made in 1937). The subsequent area of his work includes texts on social problems and their prevention, while the last one - somehow arising from the others - constituting for him a certain background and context, are letters referring to scouting. His scientific achievements also includes sketches of papers he presented, mostly about anti-alcohol movements and scouting, and articles published in social and educational science journals.

Strumiłło's scientific legacy includes his publishing activities ${ }^{13}$. Books and brochures by the author are worth mentioning: the most important ones include: Harcerstwo a szkoła, Olimpiada skautowa w Kopenhadze [Scouting and school, Scout Olympics in Copenhagen] ${ }^{14}$ (1925), O poziom kształcenia nauczycieli [About the level of teacher education] ${ }^{15}$ (1939), Psychological foundation of the Scout Spirit ${ }^{16}$, and Great men as educators in boy scout troops ${ }^{17}$. Strumiłło was also the author of several chapters in books, among which the following deserve attention: 'Harcerstwo a szkoła' [Scouting and the school] published in the Higiena szkolna [School Hygiene] textbook ${ }^{18}$ and 'Nasze dziesięciolecie' [Our tenth anniversary] in Harcerstwo Śląskie 1920-1930 ${ }^{19}$.

In addition, Strumiłło published in several magazines, mostly devoted to scouting, anti-alcohol activism, in addition to pedagogical and philosophical journals. Finding all the articles of his authorship is extremely difficult due to the fact that Strumiłło used many pseudonyms and abbreviations; known to include: his

${ }^{12}$ Ibidem.

${ }^{13}$ It includes scientific publications and journalism. In the first, Strumiłło presents his views in the field of upbringing, education and training, often transferring them to the field of scouting.

${ }_{14}$ Tadeusz Strumiłło, Olimpiada skautowa w Kopenhadze, copy of Szkoła Powszechna (Warszawa: Wydawnictwo Naczelnictwa ZHP 1925), Archiwum PAN (APAN), IIII-97, j. 127, k. 1-8.

${ }_{15}$ Tadeusz Strumiłło, O poziom ksztatcenia nauczycieli, copy of Muzeum (Lwów: Drukarnia Ekonomia 1939).

${ }_{16}$ Tadeusz Strumiłło, Psychological foundation of the Scout Spirit (Warszawa: Naczelnictwo Związku Harcerstwa Polskiego ca. 1923).

17 Tadeusz Strumiłło, Great men as educators in boy scout troops (no place provided, printed by Dyra and Jappesen ca. 1924).

18 Tadeusz Strumiłło, „Harcerstwo a szkoła”, in: Higiena szkolna, ed. Stanisław Kopczyński (Warszawa-Poznań-Lwów-Lublin-Łódź-Wilno: Ed. M. Arcta 1921), 733-747.

19 Tadeusz Strumiłło, "Nasze dziesięciolecie", in: Harcerstwo Śląskie 1920-1930 (Katowice: Nakładem Zarządu Śląskiego Oddziału Z.H.P. 1931), 3-7. 
scouting nickname - Szumiący Dąb [Rustling Oak] ${ }^{20}$ and the derivative, Dąb ${ }^{21}$; coming from the genealogy of his family - T. Dąbrowa ${ }^{22}$, Tad. Dąbrowa ${ }^{23}$, and Tadeusz Dąbrowa ${ }^{24} ; \mathrm{S}^{25}$ It is possible that he also used other, not yet identified nicknames. Manuscripts of some of the above publications have survived.

The most numerous publications by Strumiłło were printed in the Harcmistrz scouting magazine (1919-1933), which appeared in the years 1921-1923. He partially edited and funded it. Their subject matter oscillates around the organisation of the scouting movement (scout law and ideology, tasks and activities of the movement), education, and self-education through scouting. There are also reports from scout meetings and rallies taking place in Poland and abroad, in which he participated, enriched by his personal notes and orders issued as the Chief Inspector of Polish Scouting, showing Strumiłło as a contributor to the development of scouting in Poland.

Among other periodicals dealing with scouting, Strumiłło's journalistic activities included writing for the Harcerstwo and Skaut magazines (he also collaborated, among others, with Andrzej Małkowski and Ignacy Kozielewski ${ }^{26}$ ), Strażnica Harcerska, Skaut Słowiański and Czuj Duch. His articles were published in respected education science journals, such as Szkoła Powszechna, Chowanna, Ruch Pedagogiczny, Przeglad Pedagogiczny and Muzeum, as well as in the philosophical journals Przeglad Filozoficzny and Ruch Filozoficzny. He published reviews of magazines and books in Ruch Filozoficzny and Wychowanie Fizyczne. His weekly scouting chronicle entitled 'Ze świata skautowego' [From the scouting world] came out in the weekly Głos Lubelski, and in a series of texts in Ognisko he published his translation of Robert Baden-Powell's Wolf Cubs.

When he joined Eleusis in February $1906^{27}$, a patriotic and religious association, he published in the magazine under the same title. The subject matter of his texts focused on issues related to the ideological assumptions and organisational

20 Antoni Olbromski, "Harcerstwo śląskie w czasie plebiscytu", in: Harcerstwo Ślaskie 1920-1930 (Katowice: many authors, Zarząd Śląski Oddziału Z.H.P. 1931), 11.

${ }^{21}$ Stownik pseudonimów pisarzy polskich XV w.-1970 r., vol. 4, ed. Edmund Jankowski (Wrocław: Zakład Narodowy im. Ossolińskich 1996), 663.

${ }^{22}$ The nickname comes from the family genealogy. The Strumiłłos' coat of arms was Dąbrowa. Jerzy Illg, “Strumiłłowie w Książniczkach”, Naddłubniańskie Pejzaże 3 (2014), 2.

${ }^{23}$ He used this pseudonym in volume VI of the Eleusis magazine that came out in Lviv in 1911. T. Strumiłło says that this was his nickname in: "Relacja osobista z udziału w tajnej pracy skautowej w Polsce", Harcmistrz 10 (1933), 174.

${ }^{24}$ T. Strumilło used such signature as editor of the third volume of the Eleusis magazine.

${ }_{25}$ T. Strumiłło used such signature in the Czuj Duch scouting magazine. Izabella Budzińska-Kozłowska, Czuj Duch: czasopismo harcerskie: 1922-1926, 1932-1935 (Poznań: Związek Harcerstwa Polskiego 1980), 51.

${ }^{26}$ Redakcja “Strażnicy”, “Szumiący Dębie!”, Strażnica Harcerska 6 (1931), 65-66.

${ }^{27}$ T. Strumiłło sworn quadruple abstinence from tobacco, alcohol, gambling, and debauchery at the hands of Wincenty Lutosławski on 6 February 1906. Tadeusz Strumiłło, Kwestionariusz działaczy trzeźwościowych, Biblioteka Uniwersytecka KUL (BUKUL), rps 944, typescript, k. 198. 
activities of the association, and the concept of God in Juliusz Słowacki's writing. In addition, he prepared three issues of the Eleusis magazine for printing: II (1907), III/IV (1908) and VI (1910) ${ }^{28}$, two of which were edited by him - III/IV and VI - released as the Journal of the Filaret Congress.

Alongside the extensive journalistic activity, Strumiłło was involved in editing magazines. Beside the above-mentioned co-editing of Harcmistrz and Skaut, he co-edited, with Jan Dobrowolski (chief editor) and Roman Gierczyński, Myśl Filarecka (1928), a magazine devoted to "soul improvement and issues of virtue and courage" 29 through striving for Filaret perfection. Understanding the "improvement of souls" as working "on improving one's own soul, refinement and purification of individual and national character" 30 , the editors addressed the magazine to all those making this kind of effort. Despite plans to issue the magazine as a quarterly or monthly, only one issue appeared ${ }^{31}$.

Other periodicals which Strumiłło edited or had an impact on their content, include: Młodzież, Nowe Życie issued in Vienna, where he lived during World War I (1915), and Orka (1916) ${ }^{32}$. He edited the last two together with Ignacy Kozielewski.

Strumiłło was valued by his contemporaries for his flourishing activity and his views, therefore he received requests from editors of magazines to send articles for publication, tales, letters to youth or poems ${ }^{33}$, on top of requests for assistance and cooperation.

The value of Strumiłło's extensive and varied legacy lies in the fact that it contains previously unpublished information about the life and activities of the educator, not only in the scouting movement and the Eleusis Association, but also in other organisations that he supported in the execution of their tasks, including documents showing the organisation of the scouting movement and the Eleusis. The scientific development of this bulk of work, outside of the rediscovery of the social activist's interesting and inspiring pedagogical thought, may also lead to changes in the views on pedagogy held to date.

${ }^{28}$ Ibidem, k. 198-199.

29 Jan Dobrowolski, Roman Gierczyński, Tadeusz Strumiłło, “Od redakcji”, Myśl Filarecka 1 (1928), 3.

${ }^{30}$ Ibidem.

${ }^{31}$ Ibidem, 32.

32 Strumiłło, Kwestionariusz ..., k. 198-199.

${ }_{33}$ Pismo od Redakcji ,Skaut” czasopismo polskiej młodzieży harcerskiej do T. Strumitly, signed by the editor's secretary, typescript, Lwów, 22.09.1924, APAN III-07, j. 76, k. 57; Pismo od Redakcji Harcerza Ślaskiego, Komendy Choragwi Ślaskiej do T. Strumiłty, signed by Editor: Redaktor Naczelny, typescript, Katowice, 22.04.1925, APAN III-97, j. 77, k. 19. 


\section{Scouting activity of Tadeusz Strumiłło}

An analysis of Strumiłło's legacy shows his huge contribution to the organisation and work of the scouting in Poland since the beginning of the movement, and partly also to the development of scouting abroad. He created, together with Andrzej Małkowski, the first Polish scout troops in Lviv in 1911, but also contributed to the promotion of scouting as the most complete form of youth self-education. Scouting was a Catholic movement in the period of Strumiłło's activity ${ }^{34}$, and he cooperated with Fr. Kazimierz Lutosławski, the scouting chaplain. Strumiłło saw in it a chance for the moral rebirth of the nation. Strumiłło's activity has not yet been analysed scientifically, and the emerging rudimentary information is limited to a historical outline of the functions he performed or his activities for the scouts.

Andrzej Małkowski and Jerzy Grodyński had an unquestionable influence on Strumiłło's becoming involved in scouting. At the Lviv meetings of the Eleusis, they argued that scouting activities complemented the civic and educational ideas of the Elses ${ }^{35}$. In addition, Małkowski, while preparing the Polish translation of the book by Robert Baden-Powell Scouting for boys (1908), which he did as a punishment for being late to practice of the Zarzewie Youth Organisation for Independence, turned to Strumiłło with problems concerning the language, and their conversations often came down to the design of the implementation of scouting in Poland ${ }^{36}$.

Strumiłło began his active participation in scouting by attending a teacher course in Skole in the summer of 1911 after which, together with other Elses, he joined in the promotion of the idea of scouting ${ }^{37}$. The following year, along with Jerzy Grodyński, he led the first course in the Poznan area, the result of which was the founding of the District Scout Command for the Prussian partition ${ }^{38}$.

Strumiłło was often involved in the organisation of courses and camps for instructors, presenting lectures or embracing their leadership. He participated in the $1^{\text {st }}$ Congress of Troop and Platoon Leaders of Polish Scouting Troops in Lviv (March 1912) ${ }^{39}$; the Chieftaincies Scout instructor course in Skole (1914) ${ }^{40}$;

${ }^{34}$ Cf. Janina Kostkiewicz, "Polskie harcerstwo lat 1918-1939 jako ruch katolicki”, in: eadem, Kierunki i koncepcje pedagogiki katolickiej w Polsce 1918-1939 (Kraków: Oficyna Wydawnicza „Impuls” 2013), 635-642; Bogusław Śliwerski, "Przywrócić pamięć harcerskiej myśli pedagogicznej”, Polska Myśl Pedagogiczna 4 (2018), 19-29.

${ }^{35}$ Strumiłło, "Relacja...", 173.

${ }^{36}$ Ibidem.

${ }^{37}$ Ibidem, 174.

38 Ibidem.

${ }^{39}$ Glass, "Budujemy...", 29.

${ }^{40}$ Władysław Nakresz, Harcerze w bojach: przyczynek do udziału młodzieży polskiej $w$ walkach o niepodległość ojczyzny w latach 1914-1921 (cz. I), reprint (Warszawa: Związek Harcerstwa Rzeczypospolitej 2011), 21. 
the $1^{\text {st }}$ Wielkopolska Instructor Course in Pożegów (1919) ${ }^{41}$, and in the Pan-Slavic Scouting Instructors Camp in Bucze $(1932)^{42}$. His lectures promoted the ideals of scouting and outlined the tasks that the developing movement stood before.

Strumiłło's action for the development of scouting also included co-organising troops. Supporting the ideals of scouting and desiring to pass them on within Polish territory, Strumiłło, Małkowski, Grodyński, and Kozielewski organised the first Polish scout troops in $1911^{43}$ in the Austrian partition of Poland. Later, Strumiłło established scout troops in places where he stayed for longer periods of time, for example while studying in Berlin at the Friedrich Wilhelms University in 1912, where he founded the first underground scout troop for students ${ }^{44}$ and in Vienna, where he organised scouting among Polish refugees during World War I ${ }^{45}$.

Faithful in his life to the ideals of abstinence and the principles of the Eleusis, Strumiłło made every effort to transplant them to the grounds of scouting. As a member of the Eleusis established by Wincenty Lutosławski, which was promoting quaternary abstinence from alcohol, smoking, gambling, and debauchery, he greatly influenced the grounding of the idea of abstinence and anti-addiction in scouting. He was a co-author of the first edition of the Scout law - and especially the tenth point - on abstinence ${ }^{46}$. According to Aleksander Kamiński, in persuading his opponents of abstinence, Strumiłło used the best arguments. He used to say:

Scouting is not an association for entertainment, chasing the peculiarities of life; it is an association of young people united in the struggle for a better man and a better world by the exercise of human resilience and improving the environment; if you decide not to drink alcohol or smoke cigarettes, it is a start to having one of the most enduring exercises in fortitude and an action to improve the environment ${ }^{47}$.

Strumiłło promoted the achievements of Polish Scouting abroad, e.g. the Cub Scout movement, and transferred the achievements of international scouting to Poland. He participated in many international scout conferences and meetings, and after the death of Andrzej Małkowski in January 1919 until the outbreak of

${ }^{41}$ Antoni Nowak, Skauci poznańscy w walce o polskość i niepodległość 1911-1920, edited for printing by Zbigniew Pilarczyk (Poznań: Komenda Chorągwi Wielkopolskiej ZHP 1994), $116-117$.

${ }^{42}$ No author provided, "Wszechsłowiański obóz instruktorów harcerstwa", Nowy Kurier 112 (1932), 3.

${ }^{43}$ Eugeniusz Piasecki, "Wyzwolenie - a polski ruch harcowy", Wyzwolenie 5 (1912), 68-70.

Cf. Strumiłło, Kwestionariusz ..., k. 198-199.

${ }_{44}$ The troop broke up after the departure of the founder. Strumiłło, "Relacja...", 174.

${ }^{45}$ Ludwik Madej, Dzieje Zwiazku Harcerstwa Polskiego w Puszczykowie 1932-1950, vol. 4 (Puszczykowo: no publisher provided 1912), 138.

${ }^{46}$ Ibidem.

${ }^{47}$ Aleksander Kamiński, Tadeusz Strumiłto, APAN III-97, typescript, j. 157, k. 1-2. 
World War II, he was often the main representative of Polish scouting in discussions and presented papers. He represented Poland, among others, at the Third Scout Congress in Birmingham (1913) ${ }^{48}$; the International Scout Conference in Paris (1922) ${ }^{49}$; the Third International Conference of Chiefs in Copenhagen, where he gave a lecture on 'Troop patrons' $(1924)^{50}$; the $6^{\text {th }}$ International Scout Conference in Baden-Baden near Vienna, where he presented a paper entitled 'On the psychological basis of scouting ideology' $(1931)^{51}$; the $7^{\text {th }}$ International Scout Conference in Gödöllo" near Budapest combined with the $4^{\text {th }}$ Jamboree, where he presented a paper on 'The importance of camping in scouting' $(1933)^{52}$; the International Scout Conference in London (1934); the $8^{\text {th }}$ International Scout Conference in Stockholm with a paper entitled 'A few comments on joint action' $(1935)^{53}$; the $5^{\text {th }}$ World Scout Rally in Vogelenzang-Bloemendaal in Holland (1937), and the International Conference of Wolf Cub Instructors at Gilwell Park in England (1938) ${ }^{54}$.

Strumiłło also delivered lectures and took the floor in debates during national scouting conferences and rallies. He participated, among others, in the Congress of Scout Educators in Kraków $(1918)^{55}$; the $1^{\text {st }}$ Men's Instructor Conference in Brest on the Bug $(1923)^{56}$; the National Scout Rally in Warsaw $(1924)^{57}$; the Decade of Scouting Unification celebrations in Warsaw $(1928)^{58}$; the Cub Scout Conference in Nierodzim $(1934)^{59}$; the $1^{\text {st }}$ Teacher Scout Conference $(1935)^{60}$ and the Scout International Conference in Spała $(1935)^{61}$. Furthermore, he participated in many general meetings of the Supreme Command and the Chieftancy, and since 1919 also in the meetings of the Supreme Scout Council. After the end

${ }^{48}$ No author provided, "Wycieczka skautów polskich na trzeci zjazd skautowy angielski do Birmingham", Skaut 3 (1914), 12.

${ }^{49}$ Chudy Wilk, "Międzynarodowy Kongres Skautowy”, Ognisko 15 (1922), 9-10.

50 No author provided, "Międzynarodowa Konferencja w Kopenhadze", Wychowanie Fizyczne 7-12 (1924), 126.

51 Tadeusz Strumiłło, “9-ta światowa konferencja skautowa w Hadze”, Harcerstwo 3-4 (1937), 136.

52 Ibidem.

53 Ibidem, 136-137.

54 Aleksander Kamiński, "Sprawozdanie z udziału polskich instruktorów zuchowych z Międzynarodowej Konferencji Wilczęcej w Gilwell Park (Anglia)", Harcerstwo 5 (1938), 218-219, 221.

${ }_{55}$ Tadeusz Strumiłło, Sprawozdanie ze Zjazdu Wychowawców Harcerskich w Krakowie przez Dra. T. Strumilte, referenta M-wa W.R. i O.P., APAN III-97, typescript, j. 74, k. 3.

56 No author provided, "I Konferencja Instruktorska Męska”, Harcmistrz 1 (1923), 6.

${ }^{57}$ Harcerstwo polskie: album harcerski, ed. Stanisław Sedlaczek, Lech Grabowski (Warszawa: Naczelnictwo ZHP 1925), 23, 25.

58 No author provided, "Uroczystość dziesięciolecia w stolicy”, Harcmistrz 12 (1928), 193.

59 Biały Lis (Stanisław Mościcki), "Konferencja zuchowa w Nierodzimiu 27-31 XII 1934", W Kręu Wodzów 2 (1935), 27.

${ }^{60}$ No author provided, "I Harcerska Konferencja Nauczycielska", Harcerstwo 1 (1936), 15-16, 24-25.

${ }^{61}$ Tadeusz Pietras, "Międzynarodowa Konferencja Zuchowa w Spale”, Harcerstwo 3 (1935), 170. 
of World War II, Strumiłło joined in the reconstruction of the Eleusis, and since 1956 also the reconstruction of scouting. At the National Scout Activist Congress in Łódź in December 1956, he was elected to the Supreme Council of the Polish Scouting Association (Związek Harcerstwa Polskiego, ZHP), and after a few days he was entrusted with the presidency of the Historical Commission of the Supreme Council of the Polish Scouting Association ${ }^{62}$. One could say that he actively participated in all activities aimed at building scouting, both nationwide and at a global level.

Engaging in organisational activities for the scouts in Poland, Strumiłło held various positions in the scouting organisation. In the initial stage of the movement he was the Secretary of the General Scout Command in Lviv (1911), where he coordinated the work of the Union of Hope groups and scouting ${ }^{63}$. In the following years, Strumiłło attended scouting courses, maintained a list of Małopolska's troops, and in his lectures he promoted the principles of the growing movement ${ }^{64}$.

In the restored Poland, during the years 1918-1921, Strumiłło was the Chief Inspector at the Ministry of Religion and Public Education. As a promoter of the unification of the scouts, he participated in the Unification Rally in Lublin (November 1918), where he was elected to the Supreme Council of Scouts, and at the next congress in Zwierzyniec he took over its presidency. He presented the issues hindering the union and deepening of Strumiłło's scouting work at the Third Annual Congress of Scouting in the former Congress Poland in 1918 in a paper on 'The deepening of scouting', in which he outlined his plan for its recovery ${ }^{65}$. Strumiłło continued his organisational work in scouting by entering, two years later, the first Chieftaincy of the Polish Scouting Association, first as vice-chairman of the Polish Scouting Association, and later as chairman (1923-1925). In the following years, he continued as a member of the Supreme Council of Scouts ${ }^{66}$. In addition, outside of the country, Strumiłło served as chairman of the Office of Slavonic Scouts, based in Prague (1926-1931) and was a member of the 9-man World Scout Committee (elected in 1933, 1935, and 1939) ${ }^{67}$.

Strumiłło's input into the development of scouting after World War I is recognised in the Strażnica Harcerska magazine, in an article on the occasion of the $20^{\text {th }}$ anniversary of his work in this field:

${ }^{62}$ Romaniuk, “Tadeusz Strumiłło...”, 367.

${ }^{63}$ Strumiłło, "Relacja...", 174.

${ }^{64}$ Madej, Dzieje..., 138.

${ }^{65}$ No author provided, "Skauting polski (dokończenie)", Przewodnik Gimnastyczny Sokót 5 (1919), 20.

${ }^{66}$ Strumiłło, Kwestionariusz ..., k. 198-199.

${ }^{67}$ Ewa Strumiłło-Jaxa Chamiec, “Życiorys T. Strumiłły”, in: Sieci Historii 6 (2016), 23-25. 
At the very beginning of the Polish state, which is being organised from scratch, we see you again, at the educational scout outpost, of paramount importance: as a chief Scoutmaster, you are organising Polish Scouting of the former Russian partition, and also striving for the creation of one great all-Polish scouting. The fact that you have accepted such an post clearly demonstrates your faith in scouting and your consequence: if scouting is to spiritually restore Poland, one just needs to fully devote oneself to it. You were one of the main founders of the rising ZHP, first in the form of an inter-organisational agreement, and then in the form of a single organisation. Under your direction, individual organisations merged into one single body; the fact that full spiritual union has not yet occurred is not your fault. And as an inspector and as chairman of the association, in very difficult moments for you, and then only as a member of the Supreme Council, you have been of great service to scouting, an always vigilant guardian of its pure, healthy direction ${ }^{68}$.

Strumiłło received the Officer's Cross of Reborn Poland (1925) for his contribution to the development of scouting ${ }^{69}$, a bronze medal for "long service" (1938), Honorary Distinctions (1921), and the Scout Eagle (1921). He also bore the honorary title of the Scoutmaster of the Republic ${ }^{70}$. Currently, preserving the memory of Strumiłło is the task of the Instytut Strumiłły association located in Książniczki in the Lesser Poland Voivodeship, the educator's hometown.

Strumiłło's contribution, that of actively participating in the activities aimed at building scouting, first Polish, then international, is undisputed. Engaging in the emerging Polish scouting movement from the start, influencing its ideology and direction of development, Strumiłło contributed to its dissemination as the fullest form of youth self-education. He saw scouting as a way for the revival of the moral man. The personality and work of this outstanding educator was marginalised and overlooked after his death because of the promotion of other values by the state, contrary to those confessed by Strumiłło, a religious man, a teetotaller, scout and Els, who lived according to the Scout Law.

\section{Conclusions}

Strumiłło’s legacy, marginalised in the communist period, was forgotten and has not been analysed scientifically, even after the political changes in 1989. The emerging information concerning Strumiłło is rudimentary, and often imprecise, not showing his whole contribution to the development of scouting.

Strumiłło's involvement in the development of the scouting movement was huge. Having learned about the idea of scouting, and convinced of its validity by Andrzej Małkowski and Jerzy Grodyński, Strumiłło participated in organising

\footnotetext{
${ }^{68}$ Redakcja "Strażnicy", "Szumiący...", 65-66.

${ }^{69}$ Strumiłło, Kwestionariusz ..., k. 198-199.

${ }^{70}$ Romaniuk, "Tadeusz Strumiłło...”, 367.
} 
scouting in Poland from the very beginning of its existence. Not only did he co-create its foundations, but he actively worked in the emerging movement; occupying leading positions in the organisation from the start, he also co-created its ideological character. He established scout troops, organised and participated in instructor courses, and was one of the main actors in unifying the Polish scouts into the uniform organisation of the Polish Scouting Association; under his leadership the organisations became united. He influenced the ideology of the movement by promoting the ideas of abstinence and the fight against addictions from the Eleusis to scouting. He was one of the creators of the first published version of the scouting law, and especially article 10 on abstinence.

Participating in numerous national and international scouting conferences and meetings, he promoted the achievements of the Polish scouts abroad, and the achievements of international scouting in Poland. He contributed to the spread of scouting as the most complete form of youth self-education. Strumiłło also promoted the scouting movement by writing for magazines, where he also presented his views on education. Moreover, Strumiłło is the author of numerous publications on philosophy, pedagogy (upbringing and education), social problems and prevention, as well as the scout movement.

Strumiłło's extensive and diverse heritage is worth scientific development not only because of his outstanding achievements, but also due to his contribution to the development of scouting and other organisations in which he worked, complementing and expanding the existing knowledge about them.

\section{Działalność publikacyjna i harcerska Tadeusza Strumiłły}

Streszczenie: Pomijany w PRL dorobek wielu polskich pedagogów tworzących w okresie międzywojnia przyczynił się do zapomnienia ich spuścizny pomimo „zmiany 1989”. Przykładem tego jest Tadeusz Strumiłło, którego nieopracowana dotąd spuścizna zawiera materiały naukowe z obszaru filozoficznego, poprzez pedagogiczny, dotyczący problemów społecznych i ich profilaktyki, po związany z harcerstwem. Spuścizna ta ukazuje zarówno myśl pedagogiczną, jak i udział Strumiłły w organizowaniu i upowszechnianiu ruchu harcerskiego w Polsce, do którego wchodził przez stowarzyszenie „Eleusis” od samego początku jego istnienia na ziemiach polskich; współtworzył podwaliny harcerstwa, czynnie działał w powstałym ruchu, a zajmując w nim funkcje kierownicze, współtworzył jego charakter ideowy. W znacznym stopniu przyczynił się do zjednoczenia harcerstwa w jednolitą organizację Związku Harcerstwa Polskiego.

Słowa kluczowe: Tadeusz Strumiłło, harcerstwo, skauting, działalność publikacyjna, upowszechnianie ruchu harcerskiego 


\section{References}

Biały Lis (Mościcki, Stanisław). “Konferencja zuchowa w Nierodzimiu 27-31 XII 1934”. W Kręgu Wodzów 2 (1935), 27.

Budzińska-Kozłowska, Izabella. Czuj Duch: czasopismo harcerskie: 1922-1926, 1932-1935. Poznań: Związek Harcerstwa Polskiego, 1980.

Chudy Wilk. "Międzynarodowy Kongres Skautowy”. Ognisko 15 (1922), 9-10.

Dobrowolski, Jan, Gierczyński, Roman, Strumiłło, Tadeusz. „Od redakcji”. Myśl Filarecka 1 (1928), $1-3$.

Gaj, Jerzy. "Miejsce Tadeusza Strumiłły w historii harcerstwa". Roczniki Naukowe WSWF (1965), 103-137.

Gaj, Jerzy. “Prof. dr Tadeusz Strumiłło - wspomnienia pośmiertne”. Harcerska Kuźnia 8-10 (1958), 3-8.

Glass, Henryk. "Budujemy Z.H.P. - lata 1919-1931". Harcerski Volume Historyczny 6 (1979), t. 2, $8-10$.

Harcerstwo polskie: album harcerski, ed. Stanisław Sedlaczek, Lech Grabowski. Warszawa: Naczelnictwo Związku Harcerstwa Polskiego, 1925.

Hausner, Wojciech, Wierzbicki, Marek. Sto lat harcerstwa. Warszawa: Instytut Pamięci Narodowej, 2015.

Illg, Jerzy. “Strumiłłowie w Książniczkach”. Naddłubniańskie Pejzaże 3 (2014), 1-9.

Kamiński, Aleksander. "Sprawozdanie z udziału polskich instruktorów zuchowych z Międzynarodowej Konferencji Wilczęcej w Gilwell Parku (Anglia)”. Harcerstwo 5 (1938), 218-221.

Kamiński, Aleksander. Tadeusz Strumiłło. APAN III-97, typescript, j. 157, k. 1-2.

Kostkiewicz, Janina. "Polskie harcerstwo lat 1918-1939 jako ruch katolicki”. In: eadem, Kierunki i koncepcje pedagogiki katolickiej w Polsce 1918-1939. Kraków: Oficyna Wydawnicza „Impuls”, 2013, 635-642.

Madej, Ludwik. Dzieje Związku Harcerstwa Polskiego w Puszczykowie 1932-1950, vol. 4. Puszczykowo: no publisher provided, 1912.

Nakresz, Władysław. Harcerze w bojach: przyczynek do udziału młodzieży polskiej w walkach o niepodległość ojczyzny w latach 1914-1921 (cz. I), reprint. Warszawa: Związek Harcerstwa Rzeczypospolitej, 2011.

No author provided. "Międzynarodowa Konferencja w Kopenhadze". Wychowanie Fizyczne 7-12 (1924), 126.

No author provided. "Skauting polski (dokończenie)". Przewodnik Gimnastyczny Sokół 5 (1919), $19-20$.

No author provided. "Uroczystość dziesięciolecia w stolicy”. Harcmistrz 12 (1928), 193.

No author provided. "Wszechsłowiański obóz instruktorów harcerstwa”. Nowy Kurier 112 (1932), 3.

No author provided. "Wycieczka skautów polskich na trzeci zjazd skautowy angielski do Birmingham”. Skaut 3 (1914), 11-12.

No author provided. "I Harcerska Konferencja Nauczycielska”. Harcerstwo 1 (1936), 15-26.

No author provided. "I Konferencja Instruktorska męska”. Harcmistrz 1 (1923), 5-6.

Olbromski, Antoni. "Harcerstwo Śląskie w czasie plebiscytu”. In: Harcerstwo Śląskie 1920-1930. Katowice: joint study, Nakładem Zarządu Śląskiego Oddziału Z.H.P., 1931, 9-12.

Piasecki, Eugeniusz. “Wyzwolenie - a polski ruch harcowy”. Wyzwolenie 5 (1912), 68-70.

Pietras, Tadeusz. "Międzynarodowa Konferencja Zuchowa w Spale”. Harcerstwo 3 (1935), 170-174.

Pismo od Redakcji Harcerza Śląskiego, Komendy Choragwi Śląskiej do T. Strumiłty, signed: Redaktor Naczelny, typescript, Katowice, 22 IV 1925, APAN III-97, j. 77, k. 19.

Pismo od Redakcji "Skaut" czasopismo polskiej młodzieży harcerskiej do T. Strumiłty, signed by the editor's secretary, typescript, Lviv, 22 Sep. 1924, APAN III-97, j. 76, k. 57. 
Podgórska, Teresa. Stowarzyszenie Patriotyczno-Religijne "Eleusis" w latach 1902-1914. Lublin: Redakcja Wydawnictw Katolickiego Uniwersytetu Lubelskiego, 1999.

Redakcja “Strażnicy”. “Szumiący Dębie!”. Strażnica Harcerska 6 (1931), 65-66.

Romaniuk, Hanna. “Tadeusz Strumiłło (1884-1958)”. In: W trosce o trzeźwość narodu. Sylwetki najwybitniejszych działaczy trzeźwościowych XIX i XX wieku, vol. IV, ed. Marian Romaniuk. Warszawa: Ed. Yamaco, 2007, 365-384.

Słownik pseudonimów pisarzy polskich XV w.-1970 r., vol. 4, ed. Edmund Jankowski. Wrocław: Zakład Narodowy im. Ossolińskich 1996, 663.

Strumiłło, Tadeusz. Great men as educators in boy scout Trops. No place provided, drukarnia Dyra and Jappesen, ca. 1924.

Strumiłło, Tadeusz. "Harcerskie refleksje z podróży pedagogicznej”. Harcerstwo 1-2 (1938), 46-62.

Strumiłło, Tadeusz. "Harcerstwo a szkoła”. In: Higiena szkolna, ed. Stanisław Kopczyński. Warszawa-Poznań-Lwów-Lublin-Łódź-Wilno: Wyd. M. Arcta, 1921, 733-747.

Strumiłło, Tadeusz. Harcerstwo a szkoła. Poznań: Druk. Dziennika Polskiego, 1939.

Strumiłło, Tadeusz. Kwestionariusz działaczy trzeźwościowych. BUKUL, rps 944, typescript, k. 198-199.

Strumiłło, Tadeusz. O poziom kształcenia nauczycieli, odbitka z "Muzeum”. Lwów: Drukarnia Ekonomia, 1939.

Strumiłło, Tadeusz. Olimpiada skautowa w Kopenhadze, odbitka ze "Szkoły Powszechnej". Warszawa: Naczelnictwo Związku Harcerstwa Polskiego, 1925. APAN IIII-97, j. 127, k. 1-8.

Strumiłło, Tadeusz. Psychological foundation of the Scout Spirit. Warszawa: Naczelnictwo Związku Harcerstwa Polskiego, ca. 1923.

Strumiłło, Tadeusz. "Relacja osobista z udziału w tajnej pracy skautowej w Polsce". Harcmistrz 10 (1933), 173-175.

Strumiłło, Tadeusz. Sprawozdanie ze Zjazdu Wychowawców Harcerskich w Krakowie przez Dra. T. Strumiłte, referenta M-wa W.R. i O.P., APAN III-97, typescript, j. 74, k. 3-5.

Strumiłło, Tadeusz. "9-ta światowa konferencja skautowa w Hadze". Harcerstwo 3-4 (1937), 134-144.

Strumiłło-Jaxa Chamiec, Ewa. “Życiorys T. Strumiłły”. W Sieci Historii 6 (2016), 23-25.

Śliwerski, Bogusław. "Przywrócić pamięć harcerskiej myśli pedagogicznej”. Polska Myśl Pedagogiczna 4 (2018), 19-29.

Wojtycza, Janusz. “Strumiłło Tadeusz”. In: Harcerski słownik biograficzny, vol. I, ed. Janusz Wojtycza. Warszawa: Muzeum Harcerstwa, 2006, 205-207. 